\title{
A DÚVIDA NO ENSINO DE ÉTICA NO ENSINO MÉDIO
}

\author{
Leandro Kingeski Pachecol \\ Celso João Carminati2
}

\section{RESUMO}

Este artigo buscou refletir sobre a dúvida no ensino de ética no ensino médio, enquanto um possível procedimento pertinente ao percurso epistemológico do estudante e ou do professor, por meio da análise e respectiva transposição de algumas teses de alguns pensadores ligados à filosofia e ou à educação. Existem várias interpretações sobre o significado da dúvida, mas abordamos apenas quatro, apoiadas em teses de: i) Descartes, contidas no livro Discurso do Método (2001), que versa sobre um caminho para o aprimoramento ou à validação do conhecimento; ii e iii) Freire e de Faundez, expostas no livro Por uma Pedagogia da Pergunta (2013), que podem ser associadas, respectivamente, ao cultivo da pergunta e ao perguntar para conhecer e resolver problemas; iv) Savater, encontradas no livro As Perguntas da Vida (2001), que a reconhece enquanto uma etapa pertinente ao filosofar.

Palavras-chave: Dúvida. Ensino médio. Ensino de ética.

\section{THE DOUBT IN THE TEACHING OF ETHICS IN HIGH SCHOOL}

\begin{abstract}
This article sought to reflect on the doubt in the teaching of ethics in high school, as a possible procedure relevant to the epistemological path of the student and or teacher, through the analysis and respective transposition of some theses of some thinkers linked to philosophy and or education. There are several interpretations about the meaning of doubt, but we only address four, supported by theses: i) Descartes', contained in the book Discourse of the Method (2001), which deals with a path to the improve or validation of knowledge; ii and iii) Freire' and Faundez', exposed in the book Learning to Question (2013), which can be associated, respectively, with the cultivation of the question and with asking to know and solve
\end{abstract}

\footnotetext{
1 Mestre em Filosofia (Universidade Federal de Santa Catarina - UFSC) e Doutorando em Educação (Universidade do Estado de Santa Catarina - UDESC); Professor do Instituto Federal Catarinense - Campus Araquari - Brasil; Doutorando no Programa de Pós-graduação em Educação da UDESC; Grupo de Pesquisa Observatório de Práticas Escolares; Orcid iD: https://orcid.org/0000-0001-6728-8721. E-mail: leandro.pacheco@ifc.edu.br

2 Doutor em Educação (Universidade Federal de Santa Catarina - UFSC); Professor da Universidade do Estado de Santa Catarina - UDESC - Brasil; Professor do Programa de Pósgraduação em Educação da UDESC; Grupo de Pesquisa Observatório de Práticas Escolares; Orcid iD: https://orcid.org/0000-0002-3638-5489. E-mail: celso.carminati@udesc.br
} 
problems; iv) Savater', found in the book The Questions of Life (2001), which recognizes it as a relevant stage in philosophizing.

Keywords: Doubt. High school. Ethics teaching.

\section{LA DUDA EN LA ENSEÑANZA DE LA ÉTICA EN LA ESCUELA SECUNDARIA}

\section{RESUMEN}

Este artículo buscó reflexionar sobre la duda en la enseñanza de la ética en la escuela secundaria, como un posible procedimiento relevante para la trayectoria epistemológica del alumno y o docente, a través del análisis y respectiva transposición de algunas tesis de algunos pensadores vinculados a la filosofía y o educación. Existen varias interpretaciones sobre el significado de la duda, pero solo abordamos cuatro, sustentadas en tesis de: i) Descartes, contenido en el libro Discurso del método (2001), que trata sobre un camino para la mejora o validación del conocimiento; ii y iii) Freire y de Faundez, expuestos en el libro Por una pedagogía de la pregunta (2013), que pueden asociarse, respectivamente, con el cultivo de la pregunta y con el preguntar para conocer y resolver problemas; iv) Savater, que se encuentra en el libro Las Preguntas de la vida (2001), que lo reconoce como una etapa relevante en el filosofar.

Palabras clave: Duda. Escuela secundaria. Enseñanza de la ética.

\section{A DÚVIDA COMO PONTO DE PARTIDA}

A formação ética no ensino médio é reconhecida como um tema atual na legislação educacional brasileira, enquanto uma das finalidades do ensino médio. Tal tese tem amparo no inciso III do Art. 35 da Lei n 9.394 de 1996, que estabelece as diretrizes e as bases da educação nacional:

O ensino médio, etapa final da educação básica, com duração mínima de três anos, terá como finalidades: I - a consolidação e o aprofundamento dos conhecimentos adquiridos no ensino fundamental, possibilitando o prosseguimento de estudos; II - a preparação básica para o trabalho e a cidadania do educando, para continuar aprendendo, de modo a ser capaz de se adaptar com flexibilidade a novas condições de ocupação ou aperfeiçoamento posteriores; III - o aprimoramento do educando como pessoa humana, incluindo a formação ética e o desenvolvimento da autonomia intelectual e do pensamento crítico; IV - a compreensão dos fundamentos científico-tecnológicos dos processos produtivos, relacionando a teoria com a prática, no ensino de cada disciplina (BRASIL, 1996, Art. 35). 
Assim, a dúvida pode contribuir no percurso epistemológico do estudante e ou do professor, no contexto do ensino de ética no ensino médio? Embora a disciplina filosofia não esteja mais contemplada como disciplina obrigatória em todos os anos do ensino médio desde a reforma de 2017, nos parece que o professor de filosofia tem condições de contribuir nesta atividade de formação ética no ensino médio, ao procurar, entre outras coisas e junto com os seus estudantes, estudar e conhecer trechos de textos das éticas mais destacadas da história da filosofia, levando os estudantes a problematizarem suas existências e seu agir no mundo. Além disso, acreditamos que um dos maiores desafios de um professor que atua no ensino de ética no ensino médio pode enfrentar é pensar e fazer com que o estudante desenvolva o próprio pensar. Embora nem todo pensamento seja uma dúvida, a dúvida pode referir-se a um conhecimento que já se tem ou que se pretende ter.

Luckesi (1994) expõe que o conhecimento não se resume à retenção de informações, que podem estar em textos, livros ou em outros meios, mas na utilização ativa das informações para compreender a realidade, apropriando-se das mesmas, de modo a poder agir com adequação e coerência. A escola é entendida como uma instância mediadora de uma concepção de mundo ou de realidade, o que contribui para a reprodução do legado da humanidade, mas que tal instituição também permite uma transformação, enquanto um salto cultural do estudante. O professor tem um papel relevante neste sentido, ao procurar articular e conduzir o estudante a exercitar a sua compreensão do mundo, assim como também desenvolver uma forma crítica de agir, com independência, reciprocidade e originalidade.

É legítimo que todo professor de ética se preocupe com as ações de seus estudantes, na escola e fora da escola, mas delimitamos aqui a nossa reflexão em um passo aquém, isto é, enquanto o estudante busca tão somente conhecer antes de agir, embora em vistas do agir. Apesar da dúvida ser objeto de inúmeras interpretações desde os primórdios até hoje, elegemos aqui apenas quatro perspectivas que parecem permitir 
transposições para pensar o ensino de ética no ensino médio, a indicar um possível percurso epistemológico que poderia ser empreendido pelo estudante e ou pelo professor: i) de Descartes, obtidas a partir de teses dispostas no livro Discurso do Método (2001); ii e iii) de Freire e de Faundez, conforme proposições estabelecidas no livro Por uma Pedagogia da Pergunta (2013); e iv) de Savater, de acordo com afirmações encontradas no livro As Perguntas da Vida (2001).

\section{UM CAMINHO PARA DUVIDAR}

Marcondes (2019) propõe no livro Raízes da Dúvida: Ceticismo e Filosofia Moderna, que a dúvida tem raízes e que ela pode ser associada ao ceticismo. Explica que não há um ceticismo, mas várias concepções que não se desenvolveram de forma linear, mas com origens históricas e objetivos distintos. Expõe que na linguagem atual e cotidiana a dúvida pode ser geralmente relacionada a três significados diferentes, como questionamento, hesitação e pergunta. Propõe um painel cronológico da tradição cética, que contempla inúmeros filósofos situados na Antiguidade, Medievo, Renascimento, Modernidade e Contemporaneidade. Entre os representantes do ceticismo moderno, destaca Descartes por atribuir a dúvida um papel ativo e central em seu método.

René Descartes (2001) aborda na introdução de seu livro Discurso do Método, que pretende buscar um caminho para conduzir bem a própria razão e para procurar a verdade nas ciências. Relata na segunda parte deste livro estar isento de distrações e preocupações em uma cabana aquecida na Alemanha, durante um inverno europeu, o que contribuiu para ele propor quatro preceitos constituintes de seu método, em que o primeiro aborda a dúvida:

O primeiro era de nunca aceitar coisa alguma como verdadeira sem que a conhecesse evidentemente como tal; ou seja, evitar cuidadosamente a precipitação e a prevenção, e não incluir em meus juízos nada além daquilo que se apresentasse tão clara e distintamente a meu espírito, que eu não tivesse nenhuma ocasião de pô-lo em dúvida (DESCARTES, 2001, p. 23). 
É admissível aplicar este preceito no contexto do ensino de ética no ensino médio, em qualquer disciplina, inclusive junto à disciplina filosofia, pois tal estudante pode ser mobilizado por seu professor a considerar que o juízo acerca do que fazer ou deixar de fazer não deveria ser aceito por mera precipitação ou prevenção, mas validado por meio de conhecimentos qualificados tanto quanto possível como claros e distintos, após o exercício subjetivo da dúvida metódica. Um possível exemplo refere-se à cola ou à cópia não autorizada, ocorrida durante alguma avaliação, como um trabalho ou uma prova. Poderia o professor promover a dúvida no estudante que pede e aceita a resposta de outro colega, uma vez que existe a possibilidade de que tal resposta esteja errada. Ainda, que a atitude de cola talvez não contribua para a própria aprendizagem e que 0 maior prejudicado talvez seja o estudante que colou. E mais, se o estudante aceita a cola, então não estaria caracterizada aqui a precipitação e a prevenção? Precipitação sim, à medida que o estudante, impaciente, imediatamente aceita e reproduz a cola, ignorando os próprios conhecimentos que tem ou que poderia tentar desenvolver no decorrer da avaliação. Prevenção também, pois o estudante simplesmente segue a resposta do outro, contentando-se, como se tal resposta fosse válida, em detrimento do próprio juízo. A atitude de prevenção parece aproximar-se da atitude de aceitar o argumento da autoridade, isto é, de aceitar o que o outro falou, só porque este outro é especialista ou reconhecido em uma determinada área. Contudo, ninguém é infalível, nem mesmo o famoso colega da carteira ao lado.

Descartes (2001) explica que o caminho da dúvida visava, sobretudo, conduzir a si mesmo, mesmo que sozinho, nas trevas e lentamente, e permite examinar as opiniões que até então aceitou, substituindo-as por outras melhores ou simplesmente aceitando-as, se fossem ajustadas à razão. É presumível que estes ensinamentos possam auxiliar a compreender e a discutir no contexto do ensino de ética no ensino médio, pois não se trata, no caso, do professor promover ou condenar todas as opiniões dos estudantes relativas ao que fazer ou ao que deixar de fazer, que foram obtidas dos e ou 
com os outros no decorrer da vida, mas de poder incitar o estudante a realizar o seu próprio percurso subjetivo de validação e ou de substituição destas opiniões e mesmo das diversas éticas, pela via da dúvida racional. É possível que o estudante coloque em dúvida cada ética exposta pelo professor em sala de aula, procurando as suas fragilidades, inconsistências ou incoerências, mas que, se resistirem à dúvida, como algo claro e distinto, que possam ser admitidas como boas teorias pertinentes à compreensão da realidade e, por consequência, para também orientar o agir.

Na terceira parte do Discurso do Método, Descartes (2001) propõe-se uma moral provisória, por meio de uma analogia relativa à necessidade de que todo ser humano deveria viver em alguma casa firme e segura. A casa provisória em questão permitiria a Descartes ser feliz, enquanto são aplicados os quatro preceitos metodológicos, com destaque aqui para o primeiro, supracitado. Entende que a aplicação da dúvida racional não pode ser feita de qualquer modo, pois pode acarretar a substituição ou a reconstrução das opiniões que tem, podendo fragilizar os fundamentos da casa até então estabelecida. Apresenta então quatro máximas relativas à moral provisória: i) obedecer às leis e aos costumes de seu país - segundo as opiniões mais moderadas; ii) ser firme e resoluto nas ações - ocasião em que se não for possível discernir a opinião mais verdadeira, seguir a mais provável; iii) modificar os próprios desejos antes do que a ordem do mundo o que pode ser entendido como certa atitude de resignação; iv) investigar as ocupações humanas para escolher a melhor - o que identifica com o cultivo da própria razão e a busca de progresso no conhecimento da verdade. Ainda afirma que não pode se contentar com a opinião dos outros, sem antes examiná-la com o seu próprio juízo; e, que precisa julgar o melhor possivel para proceder da melhor maneira, conforme 0 seu entendimento avaliar uma ação como boa ou má. Conclui que não duvida só por duvidar, mas para estabelecer conhecimentos mais seguros. É admitida a hipótese de adotar uma moral provisória ao exercitar a dúvida no contexto de ensino de ética no ensino médio. Nossos estudantes estão sujeitos a todo tipo de opiniões, no decorrer de sua formação e mesmo de 
sua vida. Não há como e nem se deve impedi-las, mas talvez desenvolver no estudante a compreensão de que pode colocá-las em dúvida, para estabelecer um conhecimento, tanto quanto possível, mais seguro. Quem nunca ouviu o caso de um estudante que passou a usar drogas, bebidas, cigarros ou outras substâncias mais viciantes, por influência da opinião de um outro colega da escola? Todos têm direito à opinião, mas isto não quer dizer que toda opinião seja racionalmente justificada. O estudante pode vir a ser mobilizado pelo professor para duvidar de qualquer opinião que fundamenta uma ação moral e que, para tanto, ele pode adotar uma moral provisória, em que, no caso: i) obedece às leis e aos costumes de seu país, logo, não usa drogas lícitas e nem ilícitas, conforme determina a lei brasileira vigente. Justifica a lei o fato de que o consumo de drogas por parte de adolescentes costuma ser rechaçado pela ciência, devido aos seus vários efeitos nocivos à saúde, ente eles, a dependência; ii) procura ser determinado em relação às ações que escolhe, no caso, em jamais fazer o uso de drogas, mesmo que muitos colegas em uma festa, por exemplo, o incitem a usá-las, mas por sua determinação em não usá-las, tais colegas o deixem sem carona e no frio do inverno quando vão embora da festa; iii) entende que muitos de seus desejos não são necessários, isto é, que a tentação de 'viajar' ou ficar 'calibrado' não é condição para ser feliz, pois ele pode viver uma vida inteira e muito bem, sem consumir nenhum tipo de droga; iv) busca ser o melhor possível e a conhecer melhor, ou seja, coloca em dúvida as opiniões e os conhecimentos dos colegas que defendem o uso de drogas, por exemplo, em relação à sua composição química, efeitos nocivos etc. e entende que não deve usá-las, nem promover o seu consumo e muito menos comercializá-las. Burnyeat (apud MARCONDES, 2019) expõe que a formulação cartesiana de dúvida implica utilizar a dúvida como critério ou filtro para aceitar ou não algo, com consequências diretas para a vida prática; e, que a moral provisória se justifica até restabelecer o encontro de alguma certeza pertinente à ciência moral, de modo que as decisões morais possam estar fundamentadas. As próximas duas perspectivas, de Freire e de Faundez, situadas na Contemporaneidade, parecem pertinentes 
à promoção da dúvida no percurso epistemológico do estudante no contexto do ensino médio e tem em comum a valorização da pergunta.

\section{CULTIVO DA PERGUNTA}

Paulo Freire (2013) expõe no livro Por uma Pedagogia da Pergunta, que o modo como ensina não é o único ou o melhor, mas tão somente o que mais Ihe agrada. Entende que as suas experiências docentes procuram trabalhar com os estudantes e não para eles e muito menos sobre eles. Procura superar a crença de que o estudante existe tão somente para aprender e de que o professor existe tão somente para ensinar, pois 0 estudante ao aprender também ensina e o professor ao ensinar também aprende. Supõe-se aplicar tais teses no contexto do ensino de ética no ensino médio. Muitíssimo provavelmente, tal professor, por sua formação, tem conhecimentos relativos a diversas éticas, de modo mais aprofundado de que os seus estudantes. Contudo, nenhum professor ou estudante está pronto, acabado, pois sempre pode aprender um pouco mais, não só nos livros ou em cursos, mas com o outro, considerando, por exemplo, uma solução ética relativamente inédita. O ensino e a aprendizagem de ética, neste contexto, não precisam ocorrer apenas em uma perspectiva tradicional, vertical e com a predominância de apenas um sentido. Uma concepção tradicional de ensino pode ser encontrada em toda a história da nossa civilização, por exemplo, na Antiguidade e em um filósofo présocrático. Bulfinch (2006) relata que a primeira lição de Pitágoras era a do silêncio, isto é, de que o iniciado deveria apenas ouvir, cabendo apenas aos discípulos mais velhos fazerem perguntas, depois de anos de submissão. Este relato é confirmado por Diôgenes Laêrtios (1977), que também especifica a quantidade de anos em questão, um quinquênio. De modo adverso a esta perspectiva tradicional e coerente com a perspectiva de Freire, o professor pode oportunizar ao estudante conhecer diversas teorias éticas e orientações sobre como agir de modo autônomo, assim como também exercitar a sua autonomia em relação a tais éticas e orientações, como autor relativo ao próprio agir e não como mero destinatário relativo sobre 
como agir. É desejável que o estudante compreenda a autonomia, mas, sobretudo, a exercite.

Freire (2013) busca ver a dúvida, a curiosidade e a relativa ignorância dos estudantes como um desafio. Compreende que tais atitudes do estudante podem até abalar a sua certeza enquanto professor, mas que the permitem, na sequência, aprofundar uma reflexão crítica sobre o conteúdo tratado. Expressa que a sua docência não visa à falta de rigor e nem busca cultivar o espontaneísmo, mas sim propor conteúdos adequados em um ambiente que cultiva a pergunta. Se opõe à docência autoritária que, por sua vez, tende a impor uma verdade indiscutível ou reprimir a pergunta. Percebe o seu procedimento docente como coerente com a democracia e com a liberdade, conceitos muito valorizados na teoria, mas pouco praticados na sala de aula. Admite-se aplicar tal concepção no contexto do ensino de ética no ensino médio. Uma dúvida de um estudante sobre uma ética, expressa em uma pergunta pode sim, em certas ocasiões, ser desconcertante para o professor, até mesmo ser difícil de ser respondida, mas também uma oportunidade para o professor cultivar a dúvida do estudante, ao rever algum conceito, aprofundar algum tópico não desenvolvido na explicação ou mesmo propor alguns outros exemplos. A valorização da dúvida do estudante não parece ser incompatível com um ensino rigoroso de ética, nem indica que as diversas éticas devam ser colocadas em um segundo plano. Por outro lado, se o professor impõe de modo autoritário uma ética, por melhor que seja, obtém-se, de fato e tão somente uma moral, insuficiente à formação pretendida. O estudante precisa ter liberdade para exercitar e tornar pública a sua dúvida relativa à incompreensão de uma orientação ética - na sala de aula, tanto quanto possível, democrática - assim como também precisa respeitar o direito que cada um dos colegas tem de também duvidar. Por mais singela que possa parecer uma pergunta do estudante, ela parece indicar, no mínimo, uma tentativa do mesmo em conhecer a ética, em compreendê-la, em se apropriar da mesma. Conte e Habowski (2018) afirmam que Freire oferece contribuições à formação de ordem epistemológica e ética, à medida que 
este alerta sobre a possibilidade de pensamentos homogeneizadores de uma cultura, mesmo na sala de aula em função de uma possível ação docente autoritária, concomitante a pertinência do estudante exercitar a respectiva autonomia, liberdade, autoria e cooperação - por meio da pergunta. Sobre a pergunta Freire afirma:

Insistamos, porém, em que o centro da questão não está em fazer com a pergunta 'o que é perguntar?' um jogo intelectual, mas viver a pergunta, viver a indagação, viver a curiosidade, testemunhá-la ao estudante. O problema que, na verdade se coloca ao professor é o de, na prática, ir criando com os alunos o hábito, como virtude, de perguntar, de 'espantar-se'. Para um educador nesta posição não há perguntas bobas nem respostas definitivas. Um educador que não castra a curiosidade do educando, que se insere no movimento interno do ato de conhecer, jamais desrespeita pergunta alguma. Porque, mesmo quando a pergunta, para ele, possa parecer ingênua, mal formulada, nem sempre o é para quem a fez. Em tal caso, o papel do educador, longe de ser o de ironizar o educando, é ajudá-lo a refazer a pergunta, com o que o educando aprende, fazendo a melhor pergunta [...]. O importante, sobretudo, é ligar, sempre que possível, a pergunta e a resposta a ações que foram praticadas ou a ações que podem vir a ser praticadas ou refeitas (FREIRE, 2013, p. 24).

Não se busca cultivar no estudante a postura de perguntar por perguntar, mas sim cultivar o hábito de perguntar como atitude de alguém que vive uma questão, que se espanta com a realidade que vive. Respeita e valoriza as perguntas dos estudantes, até mesmo ajudando a refazê-las, se for preciso, assim como entende que não tem respostas definitivas. Não menos importante, Freire procura relacionar as perguntas e as respostas às ações que já foram, ocorrem ou serão praticadas. É presumível aplicar estes pensamentos no contexto do ensino de ética no ensino médio. Inúmeras questões fazem parte do cotidiano vivido pelo adolescente e muitas dessas questões tem relação direta ou indireta com a ética. Por exemplo, o estudante pode se espantar com a possibilidade de futuramente ou mesmo logo precisar vir a exercer um emprego específico, que não tinha cogitado, mas que se apresenta como uma opção, já que seu pai ficou desempregado durante a pandemia. Que dúvida o estudante pode propor? Uma básica é: aceito o emprego ou minha família passa fome? Que 
resposta o professor pode propor? Uma possível refere-se ao estudante procurar cultivar as suas próprias perguntas, de modo a aprimorar o seu conhecimento, em vistas de uma ação fundamentada. Em relação ao contexto, o estudante pode questionar se alguma das éticas estudadas pode contribuir para encontrar uma ação adequada e coerente, de modo a melhor fundamentar as suas ações presentes e futuras. Tais perguntas não configuram, por si, uma afronta à ética questionada, mas uma oportunidade do estudante, pelo cultivo da pergunta, buscar conhecer para, posteriormente agir. Faundez, na sequência, propõe outras teses pertinentes à dúvida, ainda relacionadas ao perguntar.

\section{PERGUNTAR PARA CONHECER E RESOLVER PROBLEMAS}

Antonio Faundez (2013) relata no livro Por uma Pedagogia da Pergunta, que as suas experiências no campo do ensino não procuram tão somente aprender filosofias, mas estudar filosofia para resolver problemas, assim como adotar o caminho da humildade, do diálogo democrático e da aceitação do diferente. De modo semelhante, Severino (2002) afirma que o conhecimento permite solucionar problemas que envolvem ações concretas. A admissão da aplicação destas teses de Faundez no contexto do ensino de ética no ensino médio permite buscar a aplicabilidade das diferentes éticas para ajudar a resolver os problemas dos próprios estudantes e não a aprendizagem das éticas por elas mesmas. Tanto o professor quanto o estudante, neste contexto, precisam ser humildes, ao entender que não têm todas as respostas em relação ao que fazer ou deixar de fazer; assim como precisam dialogar e procurar aceitar o diferente, de modo a viabilizar a construção do conhecimento de modo democrático, com tolerância em relação às legítimas perspectivas dos outros relativas ao que fazer ou deixar de fazer. É óbvio que a ação ética depende tão somente do próprio estudante, mas o conhecimento acerca do que fazer ou não pode ser aprimorado se refletido, tanto quanto possível, por mais de uma cabeça.

Faundez (2013) adverte que as ideias não são a realidade, mas admite que precisamos de ideias para compreender o mundo e que precisamos 
também buscar compreender como tais ideias impactam nas nossas ações. Afirma que é preciso empenho para buscar desenvolver a consciência dos valores que adotamos em relação às ações que praticamos, pois, caso contrário, podemos adotar valores vazios, que não coincidem com as nossas ações. Entende que o processo de consciência é lento, mas que tende a firmar-se diante do encontro com a própria realidade. Suposto aplicar tais pensamentos no contexto do ensino de ética no ensino médio, o professor pode explicar ao estudante que não é apropriado dispensar as ideias para compreender o mundo em que vive, mas, tão importante quanto é ter ideias relativas à realidade, é pensar como tais ideias se fazem presentes ou não em suas ações. O professor pode incentivar o estudante a procurar constituir processualmente a própria consciência, com a finalidade de procurar praticar ações adequadas e coerentes com as suas ideias que, por sua vez, estão carregadas de valores, que precisam, tanto quanto possível, visar ao bem. Como exemplo, o estudante pode ser mobilizado a tentar identificar os valores que costumam sustentar as suas boas ações, como, por exemplo, sua amizade presente na relação com os mais próximos de sua escola; sua gentileza presente no trato com todos os integrantes da comunidade escolar; sua liberalidade no trato de sua própria mesada; sua coragem quando decidiu entrar para a equipe de judô da escola; sua magnificência presente no comentar como a sua famosa equipe ganhou a gincana deste ano da escola; etc. Não se trata de remeter os estudantes a decorar valores defendidos por uma certa ética, no caso aqui, alguns exemplos de virtudes morais defendidas por Aristóteles (2001), mas a perguntar a si mesmo se tais valores indicam certo conhecimento relativo à realidade, visam o bem e se podem continuar a orientar as suas ações.

Em relação à escola Faundez (2013) afirma que vige na mesma um costume hierárquico a ser ultrapassado de que o professor, enquanto sábio, detém a verdade e que a promoção da busca pelo conhecimento por meio do diálogo é sinal de fraqueza e ignorância. Entende que, na sala de aula, é preciso procurar pela verdade juntos, enquanto uma investigação. A presunção da aplicação destas proposições no contexto do ensino de ética 
no ensino médio permite inferir que o professor e os seus estudantes precisam perguntar se vivem em uma cultura escolar que valoriza o diálogo ou privilegia a transferência de verdades por parte de uma pessoa considerada sábia em relação às demais consideradas ignorantes. A ética não é uma ciência exata e o professor precisa compreender que não tem todas as verdades relativas ao agir. Mesmo adolescente, com poucos anos de vida, o estudante tem uma vida pregressa ao ensino médio e por meio dela aprendeu a agir. $O$ estudante detém inúmeras ideias sobre a realidade e evidenciam que ele não é completamente ignorante sobre o agir. Ainda, que o conhecimento do estudante pode ser investigado, descoberto, aprimorado, confirmado ou mesmo refutado, por meio de uma atividade dialógica e coletiva, na sala de aula, de modo a poder justificar a sua ação moral que, por sua vez, depende somente de si. Sócrates (1987), fundador da ética, foi um exemplo de promotor do diálogo e da humildade como meio para examinar o respectivo conhecimento, com o intuito de evitar $\mathrm{O}$ mal e de procurar a virtude.

Sobre o ensino Faundez (2013) entende que ele deveria começar pelas perguntas porque todo conhecimento inicia com o perguntar, mas tanto o professor quanto o estudante parecem ter esquecido da pergunta de tal modo que hoje o ensino está fundado principalmente na resposta. $O$ ensino fundado nas respostas tem a marca do dado, do absoluto, atenuando ou impedindo a curiosidade e a descoberta. Supor a aplicação desta perspectiva no contexto do ensino de ética no ensino médio implica a possibilidade de desenvolver uma cultura entendida como avessa ao ensino marcado pelas respostas oriundas daquele considerado mais sábio, o professor, pois tanto este quanto o estudante podem reconhecer que 0 processo pedagógico pode privilegiar o processo epistemológico de perguntar, de exercitar a mente no sentido de buscar descobrir por conta própria, de exercitar a curiosidade no sentido de construir possíveis respostas para o comportamento a ser praticado. Um exemplo, neste sentido e em relação ao perguntar, refere-se à possibilidade do estudante propor: eu posso viver sem uma ética? O que caracteriza uma ética ou uma pessoa 
ética? Tenho que escolher uma ética ou posso criar uma? Há algum critério para avaliar uma ética como melhor que outra? É possível tentar aglutinar ou justapor duas ou mais éticas, com o intuito de obter uma ética mais poderosa? Sobre o perguntar Faundez afirma:

[...] estamos voltando ao início do conhecimento, às origens do ensinar, da pedagogia. [...] a primeira coisa que aquele que ensina deveria aprender é saber perguntar. Saber perguntar-se, saber quais são as perguntas que nos estimulam e estimulam a sociedade. Perguntas essenciais, que partam da cotidianidade, pois é nela onde estão as perguntas. Se aprendêssemos a nos perguntar sobre nossa própria existência cotidiana, todas as perguntas que exigissem resposta e todo esse processo pergunta-resposta, que constitui o caminho do conhecimento, começariam por essas perguntas básicas de nossa vida cotidiana [...] (FAUNDEZ, 2013, p. 24).

O perguntar é entendido como atividade pertinente ao ensino e que requer ser desenvolvido pelo professor e pelo estudante. Valorizar a pergunta, no processo de ensino e aprendizagem, possibilita considerar a própria existência como contexto para a busca e a promoção do conhecimento. Se for aceita a hipótese de que é possível aplicar tal entendimento relativo ao ensino de ética no ensino médio, a dúvida então expressa na pergunta permite ao estudante confrontar a respectiva existência em função da busca por algum conhecimento que, por sua vez, pode fundamentar uma ação. Uma pergunta básica do estudante, neste sentido, poderia ser: uma ética pode ajudar a fundamentar o meu conhecimento e posteriormente o meu agir, por exemplo, em relação ao lixo que eu produzo todos os dias, desde que o dia que eu nasci até o meu último dia de vida? Faundez (2012), noutro texto, expõe que a educação é nutrida por muitas ciências ou didáticas específicas, e que dentre estas últimas encontra-se a epistemologia da educação que, por sua vez, pode contribuir para pensar a formação autônoma, crítica, humana, integral e contínua, nas suas mais variadas dimensões, inclusive na dimensão ética. A seguir são expostas algumas teses de Savater que parecem pertinentes ao duvidar no percurso epistemológico do estudante e ou do professor. 


\section{DUVIDAR NO FILOSOFAR}

Fernando Savater (2001) expõe no livro As Perguntas da Vida, que o ensino de filosofia não pode limitar-se a conduzir o estudante a repetir como papagaio as opiniões alheias, mesmo filosóficas; nem ser entendido como uma revelação por alguém que sabe tudo a um ignorante que não sabe nada. Ao admitir transpor tais teses para o contexto do ensino de ética no ensino médio, infere-se que o professor pode pensar o seu ensino de tal modo que o estudante não se limite à mera reprodução das mais famosas teses éticas; e, que embora o professor possa ter conhecimentos sólidos e específicos na área de ética, ele jamais saberá tudo sobre esta temática. $\bigcirc$ professor pode reconhecer que o estudante, por mais ignorante que seja na área da ética, sempre pode evidenciar alguma sabedoria, relativa ao que fazer ou ao que deixar de fazer. De fato, um estudante de ensino médio já praticou inúmeras vezes o bem antes de chegar ao ensino médio, inclusive de modo consciente e intencional, indicando que tem conhecimentos que podem fundamentar um comportamento ético.

Ainda sobre o ensino de filosofia Savater (2001) o entende como um convite ao filosofar, enquanto um exercício que: i) requer que cada um filosofe por si mesmo; ii) trate todos os outros como se fossem filósofos, de modo autônomo e democrático, isto é, que todos tem o direito de pensar por si, assim como o dever de respeitar o direito do outro de opinar e de decidir; iii) não aceita qualquer argumento ou teoria filosófica como indiscutível; iv) é uma defesa, por buscar não só criticar o que pouco ou não conhece, assim como também por buscar contribuir para estabelecer conhecimentos. Presumir aplicar tais teses no contexto do ensino de ética no ensino médio permite pensar a possibilidade do professor desenvolver o filosofar de seu estudante, de modo que: i) pense por si mesmo, com autonomia, o que fazer ou deixar de fazer - por exemplo, que deve devolver o troco correto na cantina; ii) respeite a autonomia dos demais colegas opinarem e decidirem sobre como proceder - por exemplo, acolhe a decisão dos colegas em relação à divisão justa de tarefas para cada um em algum trabalho coletivo, como na confecção de um vídeo sobre dilemas 
morais; iii) discuta qualquer argumento de qualquer ética - por exemplo, se o niilismo denunciado por Nietzsche (2013) ainda é uma ameaça; iv) critique as morais ou as éticas, se as conhece pouco ou não conhece, sobretudo para buscar estabelecer conhecimentos pertinentes que, por sua vez, podem orientar uma respectiva ação - por exemplo, como deve ser encarada a utilidade, conforme a ética de Mill (2000). Sobre a pertinência da dúvida no contexto do filosofar, afirma Savater:

\begin{abstract}
Filosofar não deveria ser sair de dúvidas, mas entrar nelas. É claro que muito filósofos - e até os maiores! - cometem às vezes formulações peremptórias que dão a impressão de já ter encontrado respostas definitivas às perguntas que nunca podem nem devem 'fechar-se' por inteiro intelectualmente [...]. Vamos agradecer-lhes suas contribuições, mas não seguir seus dogmatismos. Há quatro coisas que nenhum bom professor de filosofia deveria esconder de seus alunos: - primeira, que não existe 'a' filosofia, mas 'as' filosofias e, sobretudo, o filosofar [...] - segunda, que [...] o empenho de filosofar é muito mais importante do que qualquer uma das pessoas que bem ou mal se dedicaram a ele; - terceira, que até os melhores filósofos disseram absurdos e cometeram erros graves; - quarta, que em determinadas questões extremamente gerais aprender a perguntar bem também é aprender a desconfiar das respostas demasiado taxativas. Filosofamos partindo do que sabemos para o que não sabemos, para 0 que parece que nunca poderemos saber totalmente; em muitas ocasiões filosofamos contra o que sabemos, ou melhor, repensando e questionando o que acreditávamos já saber. Então nunca podemos tirar nada a limpo? Sim, quando pelo menos conseguirmos orientar melhor o alcance de nossas dúvidas ou de nossas convicções (SAVATER, 2001, p. 209-210).
\end{abstract}

A dúvida não é compreendida como mera parte eventual do processo epistemológico de filosofar, mas requerida nesta atividade; pode ser associada ao perguntar; e, é pertinente ao contexto de ensino de filosofia. Quaisquer filosofias, por melhores que sejam, não devem ser seguidas como dogmas, mas como teorias suscetíveis de dúvida, pois podem conter algum erro ou absurdo. A dúvida não nasce da pura ignorância, pois requer partir de algo conhecido ou pretensamente conhecido e tem como finalidade orientar melhor o alcance das respectivas convicções. Para Schütz e Schwengber (2017), Savater pensa que o ensino de filosofia visa primordialmente o filosofar, o que implica questionar e que esta atitude, por sua vez, pode ser feita por qualquer um que pretenda 
tornar-se amigo da sabedoria e suspeitar continuamente da verdade, por esta ser falível. A ameaça do erro em qualquer conhecimento é admitida por Morin (2011) e, para fazer frente ao mesmo, propõe um princípio, denominado de incerteza racional, a ser exercitado no âmbito das atividades educativas presentes e futuras. A conjectura proposta aqui é de que é possível aplicar a compreensão de Savater no ensino de ética no ensino médio. Neste caso, o professor pode fazer com que o estudante busque compreender e desenvolver a dúvida como requerida na atividade de filosofar sobre uma ética. Várias éticas podem ser abordadas pelo professor e cada uma delas pode ser colocada em dúvida pelo estudante, com o intuito de evitar dogmas, não replicar erros ou absurdos; principalmente com o intuito de melhor orientar as respectivas convicções pertinentes ao próprio comportamento ético. Por exemplo, Kant (2007) defende em sua ética formal a aplicação irrestrita do imperativo categórico, por exemplo, de que não devo mentir porque não quero que ninguém minta para mim. Contudo, Singer (2002) propôs um problema que parece invalidar tal aplicação irrestrita, logo, evidenciando um erro ou absurdo, mais ou menos assim: durante a segunda guerra mundial, um assassino da gestapo bate à sua porta, na Alemanha, à procura injusta de judeus que estão escondidos em seu porão. O que você faria? Falaria a verdade? Não, conforme a ética utilitarista de Singer, pois a mentira neste caso seria aplicável e racionalmente justificada, para salvar vidas humanas.

Sobre o exame dos supostos conhecimentos Savater (2001) entende que ele precisa ser empreendido por meio da razão, entendida como o buscar e ponderar sobre argumentos, validados parte pela lógica e ou parte pela experiência, enquanto um procedimento intelectual crítico, que procura harmonizar o foro subjetivo ou pessoal com o foro objetivo ou universal. A razão não ocorre de modo isolado, mas na comunicação com os semelhantes, enquanto conversação, dentro de cada um e entre os envolvidos; e, enquanto convencimento razoável, ao aceitar o melhor argumento, venha de onde e de quem vier. Podemos supor aplicar tais pensamentos no contexto do ensino de ética no ensino médio. Neste caso, o 
professor pode promover a dúvida de seu estudante não de modo aleatório, mas de modo racional, ao buscar o melhor argumento relativo ao melhor comportamento ético, por exemplo, conforme a admoestação de Sócrates (1987), acerca do cuidar do ser muito antes do que cuidar do ter. Embora existam inúmeras informações ou dogmas divulgadas e difundidas na Contemporaneidade, e mesmo em outras épocas, de que é mais importante ter do que ser, cabe propor um diálogo com os estudantes sobre o seu respectivo projeto de vida, o que é a felicidade e como alcançá-la. Ao analisar o foro da respectiva experiência, é possível identificar momentos que ele ou algum colega foi feliz e que tais momentos não necessariamente estavam ligados, diretamente, à posse, ao dinheiro, ao acúmulo de bens. Por outro lado, é possível constatar inúmeros casos de pessoas bem afortunadas, mas que veem sua família desmoronar, por descontrole de um destes integrantes no trato com os outros ou consigo mesmo. Pela indução, se vários filósofos acreditavam na possibilidade da felicidade, por exemplo, Sócrates (1987), Aristóteles (2001), Epicuro (2002) etc., então talvez ela seja uma possibilidade para todos. Pela dedução, se admito que toda pessoa pode ser feliz, então eu também posso ser feliz. Pela abdução, se há pessoas que fazem votos de pobreza e mesmo assim são felizes, deve haver algum conhecimento que contribua para elas serem felizes; e, talvez eu possa descobrir quais são estes conhecimentos, de modo a indicar todas as premissas deste raciocínio. Ainda, que a felicidade no campo da ética, precisa procurar harmonizar a individualidade com a coletividade, pois todas as pessoas têm o direito de serem felizes.

\section{CONSIDERAÇÕES FINAIS}

A reflexão proposta neste artigo teve como ponto de partida a questão: a dúvida pode contribuir no percurso epistemológico do estudante e ou do professor, no contexto do ensino de ética no ensino médio? Acreditamos que o exercício de duvidar não representa todo o percurso epistemológico que um estudante ou um professor pode ou deveria desenvolver em relação ao agir. Por outro lado, a dúvida parece contribuir 
para o professor de ética no ensino médio desenvolver um percurso epistemológico que se opõe ao dogmatismo, ao autoritarismo e a mera reprodução de conhecimento. A dúvida permite a este professor compreender em relação aos próprios conhecimentos que não sabe e nunca saberá tudo sobre ética ou mesmo sobre didática, isto é, que o conhecimento ou o modo como ensina pode ser filtrado pela perspectiva da dúvida. Tal professor pode promover a dúvida na investigação, na produção e na aplicação de conhecimento do estudante, por meio do diálogo e da resolução de problemas, a serem validados pela experiência e pela lógica, com o cultivo da autoria e da cooperação, da liberdade e da democracia - na sala de aula. O professor em questão pode promover a autonomia do estudante por meio da dúvida, à medida que este é conduzido a perguntar acerca dos próprios conhecimentos que tem, em prol de mais clareza e segurança em relação ao agir melhor. A dúvida também parece contribuir no percurso epistemológico do estudante de ética no ensino médio a questionar racionalmente quaisquer opiniões, conhecimentos ou éticas, assim como a procurar evitar precipitações ou prevenções. A dúvida permite ao estudante reconhecer que ele mesmo detém conhecimentos pertinentes ao exercício ético e que tais conhecimentos também precisam ser investigados, de modo a poder orientar ou mesmo rever as suas ações. A dúvida também parece permitir ao estudante em questão pôr em relevo as questões relativas à própria existência, julgando os conhecimentos que tem, em prol de uma ação melhor. A dúvida ainda indica a possibilidade do estudante, junto com os colegas e com a orientação do professor, investigar conhecimentos provenientes de alguma ética ou pertinentes à ação ética. A dúvida deste estudante em relação a tais conhecimentos parece poder ser desenvolvida por meio do exercício de filosofar, autônomo, crítico, consciente, humilde, tolerante e coerente. Obviamente, propomos aqui apenas uma breve reflexão e esperamos que você aplique a sua dúvida racional em relação ao exposto, conforme o seu conhecimento e as suas respectivas ações desenvolvidas no ensino de ética no ensino médio. 


\section{REFERÊNCIAS}

ARISTÓTELES. Ética a Nicômaco. 4. ed. São Paulo: Martin Claret, 2001.

BRASIL. Lei n $^{\circ}$ 9.394, de 20 de dezembro de 1996. Estabelece as diretrizes e bases da educação nacional. Brasília, 1996. Disponível em:

<http://www.planalto.gov.br/ccivil_03/leis/l9394.htm>. Acesso em: 11 jun. 2021.

BULFINCH, T. O Livro de ouro da mitologia: histórias de deuses e heróis. 34 ed. Tradução de D. Jardim. Rio de janeiro: Ediouro, 2006.

CONTE, E.; HABOWSKI, A. C. A autoridade do educador no cenário tecnológico: interlocuções freireanas. Revista Interinstitucional Artes de Educar, Rio de Janeiro, v. 4, n. 2, p. 406-425, maio-ago., 2018: Dossiê 50 anos da pedagogia do oprimido: movimentos de opressões e emancipações contemporâneas na América Latina e África. Disponível em: <https://www.epublicacoes.uerj.br/index.php/riae/article/download/38035/26705>. Acesso em: 11 jun. 2021.

DESCARTES, R. Discurso do método. Tradução de M. E. Galvão. São Paulo: Martins Fontes, 2001.

DIÔGENES LAÊRTIOS. Vidas e doutrinas dos filósofos ilustres. Tradução, introdução e notas de M. da G. Cury. 2. ed. Brasília: UnB, 1977.

EPICURO. Carta sobre a felicidade: a Meneceu. Tradução e apresentação de Á. Lorencini e E. D. Carratore. São Paulo: Editora UNESP, 2002.

FAUNDEZ, A. Paulo Freire e sua influência na América Latina e na África. Revista Diálogo Educacional, Curitiba, v. 12, n. 36, p. 593-61 1, jul. 2012. Disponível em: <https://periodicos.pucpr.br/index.php/dialogoeducacional/article/view/466 3/4609>. Acesso em: 11 jun. 2021.

FREIRE, P.; FAUNDEZ, A. Por uma pedagogia da pergunta. Tradução do texto de A. Faundez e revisão técnica: H. F. da Costa. Rio de Janeiro: Paz e Terra, 2013.

KANT, I. Fundamentação da metafísica dos costumes. Tradução de P. Quintela. Lisboa: Edições 70, 2007.

LUCKESI, C. C. Filosofia da educação. São Paulo: Cortez, 1994.

MARCONDES, D. Raízes da dúvida: ceticismo e filosofia moderna. Rio de Janeiro: Zahar, 2019.

MILL, J. S. Utilitarismo. São Paulo: Martins Fontes, 2000. 
MORIN, E. Os Sete saberes necessários à educação do futuro. Tradução de Catarina E. F. da Silva e J. Sawaya; revisão técnica de Edgard de A.

Carvalho. 2. ed. São Paulo / Braślia: Cortez / UNESCO, 2011.

NIETZSCHE, F. W. A Genealogia da moral. Tradução de M. F. dos Santos. 4. ed. Petrópolis: Vozes, 2013.

PLATÃO. Defesa de Sócrates. In: Sócrates. Seleção de textos de J. A. M. Pessanha; tradução de J. Bruna. 4. ed. São Paulo: Nova Cultural, 1987.

SAVATER, F. As Perguntas da vida. Tradução de M. Stahel. São Paulo: Martins Fontes, 2001.

SCHÜTZ, J. A.; SCHWENGBER, I. L. Sobre o ensinar e o aprender filosofia: reflexões acerca da especificidade do ensino de filosofia. Revista Sofia, Vitória, v. 6, n. 3, p. 161-174, jul.-dez, 2017. Dossiê filosofia e educação: filosofia e ensino. Disponível em: <https://periodicos.ufes.br/sofia/article/view/17142/13048>. Acesso em: 11 jun. 2021.

SEVERINO, A. J. A filosofia na formação do jovem e a ressignificação de sua experiência existencial. In: KOHAN, W. (Org.). Ensino de filosofia: perspectivas. Belo Horizonte: Autêntica, 2002.

SINGER, P. Ética prática. Tradução de J. L. Camargo. 3. ed. São Paulo: Martins Fontes, 2002.

Recebido em: 17 de julho de 2021. Aprovado em: 22 de outubro de 2021. Publicado em: 20 de novembro de 2021. 